Abstracta Iranica Iranica

Revue bibliographique pour le domaine irano-aryen

Volume 32-33 | 2013

Comptes rendus des publications de 2009-2010

\title{
Oren Tal. On the identification of the ships of KZD/RY in the erased customs account from Elephantine.
}

\section{Astrid Nunn}

\section{(2) OpenEdition}

1 Journals

Édition électronique

URL : http://journals.openedition.org/abstractairanica/40432

DOI : 10.4000/abstractairanica.40432

ISSN : 1961-960X

\section{Éditeur :}

CNRS (UMR 7528 Mondes iraniens et indiens), Éditions de l'IFRI

\section{Édition imprimée}

Date de publication : 1 décembre 2013

ISSN : 0240-8910

\section{Référence électronique}

Astrid Nunn, "Oren Tal. On the identification of the ships of KZD/RY in the erased customs account from Elephantine. ", Abstracta Iranica [En ligne], Volume 32-33 | 2013, document 125, mis en ligne le 01 juillet 2016, consulté le 05 octobre 2020. URL : http://journals.openedition.org/abstractairanica/40432 ; DOI : https://doi.org/10.4000/abstractairanica.40432

Ce document a été généré automatiquement le 5 octobre 2020.

Tous droits réservés 


\title{
Oren Tal. On the identification of the ships of KZD/RY in the erased customs account from Elephantine.
}

\author{
Astrid Nunn
}

\section{RÉFÉRENCE}

Oren Tal. « On the identification of the ships of $K Z D / R Y$ in the erased customs account from Elephantine ».JNES 68/1, 2009, p. 1-8.

1 Le texte araméen d'Eléphantine "Les Pensées d'Ahiqar" a été écrit sur un texte de comptes douaniers plus ancien. Ces comptes datent de Xerxès I (475) ou d'Artaxerxès I (454). Sont énumérées les douanes à payer à l'arrivée et au départ des bateaux ioniens et phéniciens. Cet argent allait à la trésorerie achéménide. Plusieurs types de bateaux sont nommés, parmi eux le type de kzd/ry. Peu d'A. se sont penchés sur le sens de ces mots. La proposition d'interpréter kzd/ry comme un toponyme, plus exactement de l'identifier avec le Tell Ghazza/Tel Ya'oz (gzr biblique et Gazara hellénistique) a déjà été faite. Ce tell se trouve à l'embouchure du Wadi Rubin/Nahal Sorek dans la Méditerranée et a déjà été fouillé. L'A. passe ici en revue les arguments, e.a. archéologiques, et opte en faveur de cette identification. 


\section{AUTEURS}

\section{ASTRID NUNN}

Université de Munich 